\title{
The Basic Factors Driving The Intention To Pay Zakat
}

\author{
Tatik Mariyanti ${ }^{1}$, Yuswar Zaenul Basri ${ }^{2}$, Zoji Jazuli ${ }^{3}$ \\ 1,2,3 Universitas trisakti \\ Email: tatik m2002@yahoo.com ${ }^{1}$, yuswarzainulbasri@gmail.com ${ }^{2}$, \\ zouge.gazuli@gmail.com ${ }^{3}$
}

\section{To cite this document :}

Mariyanti T., Basri Y., Jazuli Z. (2022). The Basic Factors Driving The Intention To Pay Zakat. Aptisi Transactions on Management (ATM), 6(1), 30-41.

DOI :

https://doi.org/10.33050/atm.v6i1.1692

\begin{abstract}
The role of zakat is significant not only as a means of worship but also zakat has a powerful social and economic aspect. Many previous studies have found that zakat that can be appropriately managed will solve social problems such as the gap between the rich and the poor, social jealousy, etc. In addition, zakat in economic terms was also found to reduce poverty rates, encourage economic growth and increase welfare. In this study, the factors considered are knowledge, attitudes, moral norms, and descriptive norms. Knowledge is related to the ability that is generally owned by someone pertaining to tithe activities. The research method that will be used is using the structural equation model method. With this method, it is hoped that the impact, both direct and indirect, will be seen in detail. This study indicates that the knowledge of a muzzaki and the moral norms he adheres to influence the person's intention to pay zakat significantly. Furthermore, in this study, it is also known that moral norms have a stronger impact between the two, namely knowledge and moral norms. In addition, this study also found that descriptive norms and attitudes did not significantly affect the intention to pay zakat on muzakki. The results of this study can be used in building tithe intentions, especially for zakat institutions, in terms of creating and building messages and appeals that are more appropriate for muzzaki.
\end{abstract}

Keywords: Zakat, Behavioral Intentions, Knowledge of Zakat, Moral Norms, Descriptive Norms, Attitudes

\section{Introduction}

Zakat is one of the obligatory acts of worship in Islam. Zakat is included in the five pillars of Islam, which are worships that need and must be carried out by Muslims to achieve Islamic perfection. In Islam, the command of zakat is revealed through the Qur'an. In the Qur'an, there are many commands to carry out zakat. The command of zakat in the Qur'an is generally equated with the knowledge to pray. This shows how important the implementation of zakat worship in Islamic teachings is.

In Islam, zakat worship is a form of worship related to obedience to Allah's commands, but also zakat worship is a form of worship that provides social benefits. Zakat worship is one of the facilities provided by Islam in maintaining social balance in society. Besides, that zakat can guarantee social security, especially from the aspect of poverty in the community.

In addition to zakat, there are several instruments in Islamic teachings that aim to maintain social balance, including alms, infaq, and waqf. Through these four instruments, Islam seeks to maintain a balance in the even distribution of income in a community. Besides that, these instruments will also impact reducing social conflicts, especially those caused by too vast economic inequality. This is possible because, through the worship of zakat, infaq and alms and waqf will improve social relations between the rich and the poor in a community. Furthermore, 
Zakat and other instruments will also increase social awareness, a sense of mutual help, and build a sense of compassion in society.

In this study, the instrument that will be analyzed further is in terms of zakat worship. This is because zakat is a mandatory instrument among the instruments mentioned above. In this case, in the view of Islam, zakat has the greatest significant impact of these instruments. Indonesia is a country with a substantial Muslim population. Until now, there is approximately 250 million Muslim population in Indonesia. The sizeable Muslim population will undoubtedly create tremendous potential for zakat in Indonesia. Based on the KNKS in 2019, the potential amount of zakat in Indonesia could reach 230 trillion rupiahs. However, the realization of the potential of zakat is still minimal. In 2019, the completion of zakat collection in Indonesia amounted to approximately 10 trillion rupiahs. This shows that the realization of zakat collection in Indonesia is only about $4 \%$ of the potential zakat in Indonesia.

Optimization of the collection of zakat funds is needed to increase the level of community welfare. Several research results have proven that zakat has a significant impact on poverty reduction. A survey conducted on 821 poor households out of 4,646 households receiving zakat funds in Jabodetabek sourced from zakat management organizations found that the poverty of zakat recipients (mustahik) decreased by 10.79 percent after receiving zakat funds. From the perspective of the depth of poverty, it was found that the zakat intervention was able to reduce the severity of poverty by 12.12-15.97 percent. Zakat can reduce the number of low-income families from 84 percent to 74 percent [1]. Then from the aspect of the depth of poverty, zakat is also proven to reduce the poverty gap and income gap.

The research results above show that the collection of zakat funds can be used as an alternative to raising public funds to eliminate poverty systematically. The government's role in zakat management is contained in Law Number 38 of 1999 concerning zakat management which was ratified on September 23, 1999. Even so, the role and efforts of the government have not made many changes in overcoming the nation's economy (poverty), but at least The law has provided a guarantee that zakat can be managed properly.

The effectiveness of zakat management directly by the government will provide significant results and influence in poverty alleviation. Although the value achieved from the sharia law is in the pursuit of spiritual matters, it cannot be separated that the attachment of the implementation of the zakat law will result in benefit. Among them are advantages in the economic field in the form of influence on poverty alleviation. This is evident from various research results that have been carried out that the management of zakat carried out by the State in the context of obedience to the Shari'a revealed by Allah SWT can alleviate the nation's poverty problem.

Historically, zakat management directly by the government has been proven to be well implemented and can be distributed in a more targeted and targeted manner so that it affects poverty alleviation. Because the State, through its authority and power, can force every individual and group of people who meet the category of being obliged to pay zakat and hasten to issue it. The Caliph Abu Bakr ash-Siddiq has exemplified such attitudes and actions; he fought individuals or groups who were reluctant or objected to giving zakat at the beginning of his leadership. The efforts made are a form of obedience to the Shari'a that has been revealed by Allah SWT brought by the Prophet Muhammad. Then, the fruit of obedience is then always remembered by Muslims and the world that during the leadership of Caliph Umar bin Abdul Aziz, not a single community was found who was entitled to receive zakat.

By looking at the discussion above, it can be stated that efforts need to be made to increase the intention and motivation of the Indonesian Muslim community to carry out their zakat worship, this is not only because zakat is an order from Allah SWT but also because it turns out that zakat also has a broad impact in life. Social community and nation and state. So it is necessary to formulate factors that are possible to encourage intention to pay zakat based on previous literature, namely that education and knowledge about income zakat, commitment to Islam (faith), and religious knowledge can increase public awareness in paying zakat [2]. The higher the level of education, faith, and knowledge of a person about zakat, the more heightened the awareness to pay zakat, so zakat receipts will also increase. Because, after all, a person's education and knowledge indirectly affect that person's economic behavior.

Furthermore, a different study, namely researching in the Philippines, found that several factors can encourage a person's intention to be able to pay zakat, namely the first is the attitude towards zakat itself, the second is the influence of moral norms that exist within a person, and the 
third is descriptive norms or which in simple concepts are norms that most people are based on [3].

However, several studies are not under this research, such as in Kuala Lumpur, which found that attitudes, moral norms, and descriptive norms had no impact on the behavior of charitable donations. [4].

Based on the research above, this study will look at factors that can encourage a person's intention to pay zakat, including knowledge about zakat, one's attitude towards zakat, moral norms, and descriptive norms.

\section{Factors that encourage zakat intention}

Based on previous research, several factors can encourage zakat intentions. Among others are

Knowledge

Knowledge is essentially all that we know about an object, including science. There are two main ways for humans to gain a proper understanding. The first way is based on reason, and the second is simply based on experience [5].

Education, knowledge, and understanding are one of the important and decisive capitals in today's life. Joesoef (1998) once revealed the importance of education, as follows: "Education is all areas of life in choosing and fostering a good life, which is in accordance with human dignity"

From this statement it can be concluded that education or knowledge is a very important thing and cannot be separated from life. The willingness to pay zakat is a must for Muslims. It is common knowledge that paying zakat is an obligation for every Muslim. Therefore, Muslims need to have knowledge about zakat [6]. The implementation of zakat still encounters obstacles because the awareness of the Muslim community in the performance of zakat is still not followed by an adequate level of knowledge about zakat [6]. Lack of knowledge about the obligatory zakat types and the mechanism for paying zakat by Islamic law affects zakat payments made by the Muslim community.

That the zakat knowledge variable has a positive and significant effect on the motivation to pay zakat, but the zakat knowledge motivation does not significantly affect the value of zakat [7]. The study results indicate that the motivation of zakat knowledge has a significant effect on the grounds of muzakki to pay zakat. Still, the part does not have a considerable impact on the amount of zakat value. Factors of faith and knowledge of zakat affect muzakki in paying zakat. The higher the level of confidence and understanding of zakat, individual Muslims will be more inclined to pay zakat [8].

The research results described above are in line with that of Qardhawi (1997); the moral values possessed by individuals will affect their obedience to the rules. Thus ideally, when the individual has a better education, it will automatically determine the economic activity needed, in this case paying zakat.

\section{Descriptive Norm}

Descriptive norms are individual perceptions of the most appropriate behavior displayed by others. Many previous studies have found that descriptive norms are highly correlated with behavior. Descriptive norms were also found to be stronger predictors of pro-environmental behavior [9]. Descriptive norms are generally part of social norms, where social norms are defined as a shared understanding of what is considered appropriate behavior [10]. Social norms can regulate and regulate behavior through the individual's perceived possible punishment for disobedience and rewards for compliance.

Three factors influence consumer choices in buying goods/services (1) individual consumers, (2) the environment, and (3) the application of marketing strategies. The second factor, namely the environment. This means that consumers' choices of goods/services are influenced by the environment that surrounds them. When consumers buy goods/services, they are based on many considerations, for example, because they imitate their friends because their neighbors have bought them first, and so on. Thus the social interaction carried out by a person will also influence the choice of products to be purchased [11].

The theory of intention has developed, which at first only contained the theory of reasoned action, then the theory evolved into the theory of planned behavior [12]. Menurut Azwar (2006) The theory of planned behavior remains focused on two intention factors (attitudes towards 
behavior related to subjective norms) but three, where the perceived behavior control (PBC) aspect is included. [13].

Theory of Planned Behavior, research on behavioral intention to pay zakat is influenced by attitude, subjective norm, and planned behavior control. Zakat intention is a person's personal view of the tendency to bring up a behavior. It includes motivational factors that indicate how hard the effort is and how much effort the person concerned uses to display behavior [14].

\section{Attitude towards Zakat}

Attitude can be interpreted as a person's tendency to evaluate or evaluate certain behaviors positively or negatively. attitude is considered as part of the behavioral belief expectations and can be measured based on the evaluation of the results [15]. Both of these factors are found in the salient beliefs of a behavior. A salient idea is a general opinion used by a group concerning an action/behavior judgment. In other words, salient behavioral beliefs serve to link behavior with the consequences of performing that behavior. Thus, an individual can determine what is meant by a good attitude based on an evaluation of the actions that have been taken. In general, the more often an individual produces a good assessment of his behavior, he will tend to be optimistic about his behavior, and vice versa.

Attitude is the total evaluation of a particular outcome as positive or negative or good or bad, and an estimate of the likelihood of that outcome. Attitudes and behavior are mediated through behavioral intentions, and attitudes will predict preferences to behave [16]. While considering attitudes, it is clear given that general attitudes may not be able to predict behavior, but attitudes that specifically support a particular behavior at hand will predict intentions to act in the same way [17], and those intentions will, in turn, predict behavior.

\section{Moral Norms}

Much of the psychological and sociological literature contains explanations relating to moral norms. The concept of moral norms refers to the idea that people themselves can judge whether a specific behavior is right or wrong regardless of its personal or social consequences; Thus, moral norms are derived primarily from oneself [18]. Moral norms were included as an additional factor in explaining behavioral intentions. In 11 tests, mean intention prediction increased to 4 percent of the variance when moral norms were included. In addition, moral norms are beneficial when predicting prosocial behavior or behavior that has an ethical component. For example, I found a sense of personal obligation to be an essential driver of charitable giving, thus suggesting that charitable giving is a behavior with a moral component.

One of the distinctive features of the voluntary context is that individuals may have a moral obligation to help others by providing volunteer activities. Moral obligation seems to be particularly relevant to the underlying motivations associated with volunteer work, given that volunteerism meets many criteria for a moral issue or moral situation that stand out because it has meaningful consequences for others [19]. Similarly, do broad moral views predict prosocial behavior and find that individuals with general moral obligations appear to participate in volunteer work and charity giving more than those with limited responsibilities [20]. Individuals with a high sense of moral obligation may have a stronger intention to volunteer at a sporting event than individuals with a low sense of moral responsibility.

\section{Method and Literature Review}

The influence of the theory of planned behavior on voluntary activities found that moral norms and attitudes are factors that influence the intention to carry out voluntary activities [21].

Factors of education and knowledge about income zakat, commitment to Islam (faith), and religious knowledge can increase public awareness in paying zakat. The higher the level of education, faith, and knowledge of a person about zakat, the more attention paid to pay zakat, so the zakat receipts will also increase. Because, after all, a person's education and knowledge indirectly affect that person's economic behavior [2].

The moral values possessed by individuals will affect their obedience to the rules. Thus ideally, when an individual has a better education, it will automatically determine the economic action he takes, in this case paying zakat [22].

That the zakat knowledge variable has a positive and significant effect on the motivation to pay zakat, but the zakat knowledge motivation does not significantly affect the value of zakat. 
The study results indicate that the basis of zakat knowledge has a significant effect on the grounds of muzakki to pay zakat. Still, part does not have a significant impact on the value of zakat. [23].

According to the Planned Behavior theory, research on behavioral intention to pay zakat is influenced by attitude, subjective norm, and planned behavior control. Zakat intention is a person's personal view of the tendency to bring up a behavior. It includes motivational factors that indicate how hard the effort is and how much effort the person concerned uses to display behavior [24].

\section{Conceptual framework}

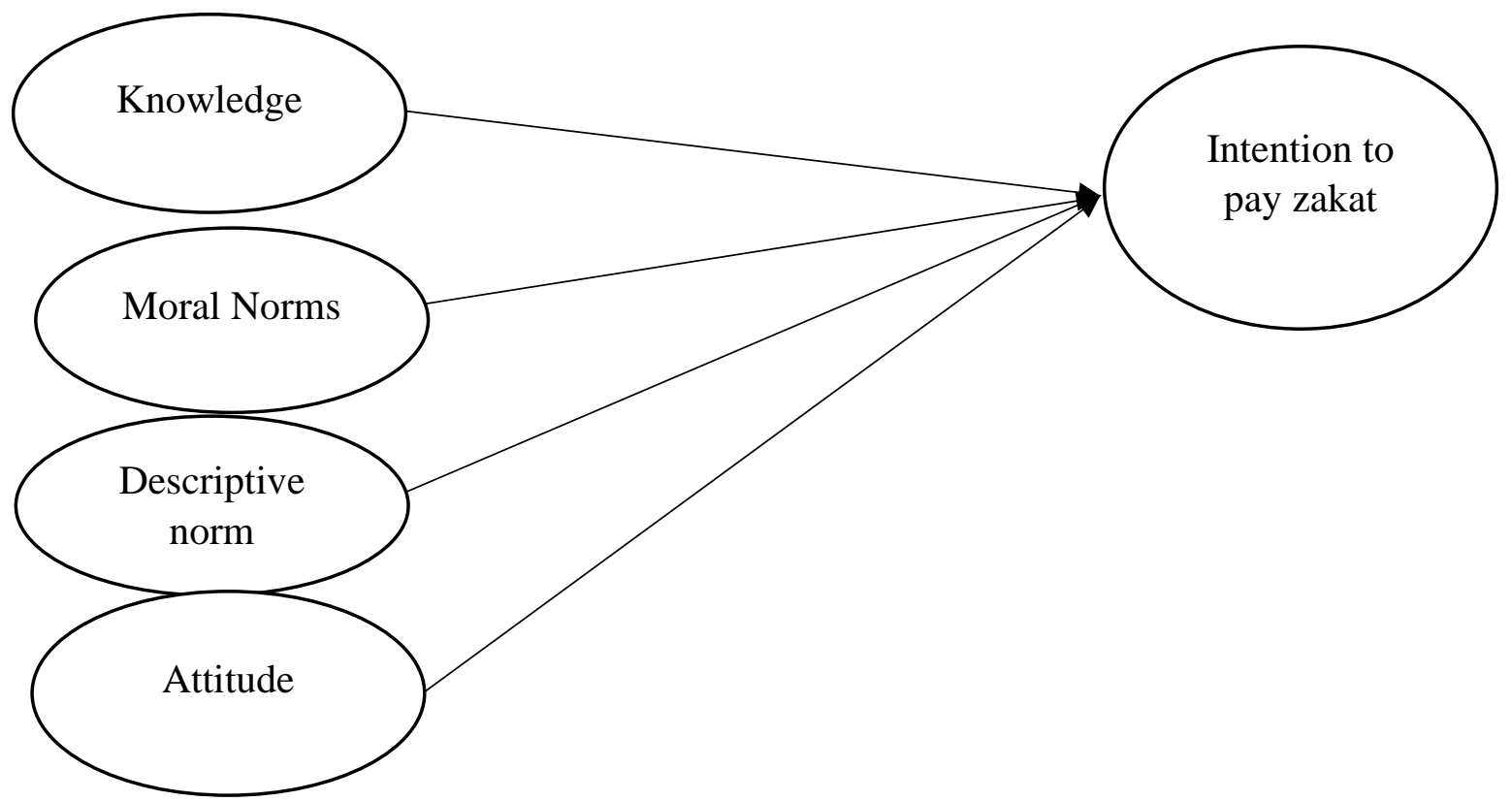

Figure 1. Frame of Mind

\section{Hypothesis Development}

The factors of education and knowledge about zakat and religious knowledge can increase public awareness in paying zakat. The higher the level of education, faith, and understanding of a person about zakat, the higher the awareness to pay zakat, so that zakat receipts will also increase. Because, after all, a person's education and knowledge indirectly affect that person's economic behavior [2].

The zakat knowledge variable has a positive and significant effect on the motivation to pay zakat, but the zakat knowledge motivation does not significantly affect the value of zakat. The study results indicate that the basis of zakat knowledge has a significant effect on the grounds of muzakki to pay zakat. Still, the part does not have a considerable impact on the value of zakat. [7].

Thus, the following hypothesis can be formed,

$\mathrm{H} 1$ : there is an effect of knowledge on the intention to pay zakat

According to the Planned Behavior theory, research on behavioral intention to pay zakat is influenced by attitude, subjective norm, and planned behavior control. Zakat intention is a person's personal view of the tendency to bring up a behavior. It includes motivational factors that indicate how hard the effort is and how much effort the person concerned uses to display behavior. tithe [25]. The influence of the theory of plan behavior on voluntary activities found that moral norms and attitudes are factors that influence the intention to carry out voluntary activities [26]. 
That attitudes, moral norms, and descriptive norms have a significant impact on tithe behavior thus will form the following hypothesis [3]:

$\mathrm{H} 2$ : there is an effect of descriptive norms on the intention to pay zakat

$\mathrm{H} 3$ : there is an influence of moral norms on the intention to pay zakat

$\mathrm{H} 4$ : there is an influence of attitude on the intention to pay zakat

\section{Research methodology}

The following research is hypothesis-testing research that will look at the influence of several factors, namely knowledge, attitudes, moral norms, and descriptive norms, on the intention to pay zakat. Thus it can be seen that there are four independent variables, namely knowledge, attitudes, moral standards, and descriptive norms, and one dependent variable, namely the intention to pay zakat.

The population of this study is Indonesian citizens who are Muslim and have income who live in Indonesia. From this population, a random sample will be taken with a total sample of 300 people.

Data collection in this study will be carried out through interviews through questionnaires distributed through the Google Form application.

This research is carried out through hypothesis testing with data processing methods using a structural equation model. This method will see the effect of the independent variable on the dependent as described in the hypothesis.

Prior to testing the hypothesis, the research instrument's quality was tested, and the goodness of fit test of this research model.

This is so that this research has good and accountable results.

\section{Results and Discussion}

\section{Descriptive Statistical Test Results}

In discussing the results of this descriptive statistical test, each variable will be discussed.

\section{Knowledge}

The following are the results of descriptive statistics from the knowledge variable

Table 1. Muzaki knowledge descriptive statistics

\begin{tabular}{|c|c|c|c|c|}
\hline & & & & \\
Knowledge & Min & Max & Average & Standard Deviation \\
\hline Zakat Calculation & 2 & 5 & 4,66 & 0,55 \\
\hline Zakat Recipients & 2 & 5 & 4,53 & 0,65 \\
\hline Zakat Payment Time & 2 & 5 & 4,60 & 0,65 \\
\hline- & 2 & 5 & 4,59 & 0,62 \\
\hline
\end{tabular}

Based on table 1 above, the average value of knowledge of the muzakki regarding zakat worship has a value of 4.59. This value indicates that the respondents' knowledge regarding zakat worship, in general, is good. The standard deviation value is 0.62 , where this value shows the level of variation of the knowledge is not too large, meaning that respondents do not understand the worship of zakat but not much..

\section{Descriptive Norm}

The following is a descriptive statistical table of descriptive norms

Table 2. Descriptive Statistics of Descriptive Norms

\begin{tabular}{|l|l|l|l|l|}
\hline Descriptive Norm & Min & Max & Average & Standard Deviation \\
\hline
\end{tabular}




\begin{tabular}{|l|l|l|l|l|}
\hline People around pay zakat & 1 & 5 & 3,65 & 0,82 \\
\hline Meet many requests for zakat & & & & \\
& 2 & 5 & 3,57 & 0,83 \\
\hline Family used to pay zakat & 1 & 5 & 3,85 & 0,69 \\
\hline- & 1 & 5 & 3,69 & 0,78 \\
\hline
\end{tabular}

Based on table 2 above, it can be seen that the average value of respondents' perceptions of this descriptive norm is 3.69 , where this value indicates that respondents' perceptions of this descriptive norm are still not good. When viewed from each indicator that measures this descriptive norm, it can be seen that there is no average value per indicator that looks much different. This can also be seen in the magnitude of the standard deviation value of 0.78 , which indicates that the variation of the respondent's perception answers is not too spread out. So, it can be stated that in general, respondents' perceptions of this descriptive value are still not good.

\section{Attitude Descriptive Statistics}

The following are descriptive statistics of attitude variables

Table 3. Descriptive Statistics Of Attitudes

\begin{tabular}{|l|l|l|l|l|}
\hline Attitude & & & & \\
\hline Happy to see people paying zakat & 1 & 5 & 4,18 & 0,68 \\
\hline Invite others to pay zakat & 1 & 5 & 4,13 & 0,69 \\
\hline Happy with the act of tithing & 2 & 5 & 4,11 & 0,62 \\
\hline- & 1 & 5 & 4,14 & 0,66 \\
\hline
\end{tabular}

Based on table 3. As mentioned above, it can be seen that the average size of respondents' perceptions of attitudes is 4.14 , where this value indicates that respondents' perceptions of this attitude are good, furthermore, in table 3 . It is also seen that the standard deviation value is 0.66 , which means that the variation of the variable is relatively uniform.

\section{Moral Norms}

Here are descriptive statistics of moral norms,

Table 4. Descriptive Statistics On Moral Norms

\begin{tabular}{|l|l|l|l|l|}
\hline Moral Norms & Min & Max & Average & Standard Deviation \\
\hline Pay zakat with self-awareness & 3 & 5 & 4,73 & 0,48 \\
\hline Pay zakat to help others & 2 & 5 & 4,35 & 0,81 \\
\hline Pay zakat not because of obligation & 2 & 5 & 4,76 & 0,51 \\
\hline- & 2 & 5 & 4,61 & 0,62 \\
\hline
\end{tabular}

In Table 4. Above, it can be seen that the average value on respondents' perceptions of their moral norms is 4.61, where this value indicates that in respondents' perceptions, they already have good moral norms. The standard deviation value also shows a value of 0.62 . This shows that although several respondents have different opinions, they tend to have a uniform idea.

\section{Zakat Intention}

Management Information Systems on Integrated Student and Lecturer Data (Penny Hendriyati) 
Berikut adalah tabel statistic deskriptif dari intensi zakat

Table 5. Descriptive Statistics on Zakat Intentions

\begin{tabular}{|l|l|l|l|l|}
\hline Zakat Intention & Min & Max & Average & Standard Deviation \\
\hline Pay excessive zakat & 3 & 5 & 4,89 & 0,35 \\
\hline Set aside income every month & 2 & 5 & 4,83 & 0,43 \\
\hline Pay regular zakat every year & 3 & 5 & 4,81 & 0,47 \\
\hline- & 2 & 5 & 4,84 & 0,42 \\
\hline
\end{tabular}

Based on table 5. Above, it can be seen that the average respondent's perception of the zakat intention they have is 4.84 , where this value indicates that in general, the respondents' zakat intention is good, leading to very good, which is approaching a value of 5 . From the standard deviation, it can be seen that it has a value of 0.42 , which indicates that the variation in the opinion of the respondents leads to a more homogeneous opinion.

\section{Model Fit Test Results}

Testing the fit or goodness of fit model on the structural equation model is one of the most critical tests. This is because in this test will be seen the feasibility of the model used in the study. If there is feasibility, the model means that it can indeed be used to reflect the object of the study. However, if it is not feasible, there need to be improvements in the model development carried out in the study.

Table 6. Goodness of Fit

\begin{tabular}{|l|l|l|l|}
\hline Goodness of Fit & Condition & Results & Conclusion \\
\hline P qi square & $>0,05$ & \multicolumn{1}{|c|}{0} & no fit \\
\hline GFI & $>0,90$ & .884 & marginal fit \\
\hline NFI & $>0,90$ & .885 & marginal fit \\
\hline RFI & $>0,90$ & .849 & marginal fit \\
\hline IFI & $>0,90$ & .932 & fit \\
\hline TLI & $>0,90$ & .909 & fit \\
\hline CFI & $>0,90$ & .931 & fit \\
\hline \multicolumn{1}{|c|}{ RMSEA } & & .085 & no fit \\
\hline
\end{tabular}

Based on the table above, in general, it can be seen that the level of eligibility is between marginal fit and fit even though several criteria do not pass or do not fit. However, when viewed broadly, the model used in this study is a model suitable for use in research.

\section{Hypothesis test results}

Below will be shown the results of the hypothesis testing of this study,

Table 7. Hypothesis test results

\begin{tabular}{|l|l|l|l|l|l|}
\hline \multicolumn{2}{|l|}{ Hypothesis } & Estimate & $P$ & \\
\hline Knowledge & $>$ & zakat intention & .274 & .018 & Accepted \\
\hline
\end{tabular}




\begin{tabular}{|l|l|l|c|c|l|}
\hline Descriptive norm & $>$ & zakat intention & .055 & .461 & rejected \\
\hline Attitude & $>$ & zakat intention & .049 & .499 & rejected \\
\hline Moral norms & $>$ & zakat intention & .516 & $* \star *$ & Accepted \\
\hline
\end{tabular}

Based on table 7 above, it can be interpreted the test results of each of these hypotheses in this study as follows,

\section{Hypothesis 1}

This first hypothesis is a hypothesis that will look at the influence of the knowledge possessed by muzaki regarding zakat worship and its rules on the intentions of the muzaki in paying their zakat. Thus, the following hypothesis will be formed:

Ho: there is no effect of muzzaki knowledge on the intention to pay zakat Ha: there is an effect of muzzaki knowledge on the intention to pay zakat

Based on table 7. It is known that the probability value $(P)$ of this hypothesis is 0.018 , where the probability value is less than $0.05(P<0.05)$, so it can be stated that $H o$ is rejected and $\mathrm{Ha}$ is accepted. Thus, it can be concluded that there is a significant influence of the knowledge of a muzzaki on the intentions of the muzzaki in paying zakat.

The findings in this study are by the findings of several previous studies, which also found that the level of muzzaki knowledge had a positive effect on the intention of tithing [8]. In table 7 above, it can also be seen that the magnitude of the influence of knowledge on the intention to pay zakat on muzzaki. Where it is seen that this influence is worth 0.274 , this value shows that the impact of knowledge on the intention to pay zakat is still weak.

\section{Hypothesis 2}

This second hypothesis will look at the effect of descriptive norms on the intentions of a muzzaki in paying zakat, so that it will lead to the following hypothesis, Ho: there is no influence of descriptive norms on the intention to pay zakat Ha: there is an effect of descriptive norms on the intention to pay zakat.

Based on table 7 the results of the hypothesis test above, it can be seen that the magnitude of the probability of this hypothesis is 0.461 where the value of this hypothesis is more than 0.05 ( $p>0.05$ ) thus it can be stated that $\mathrm{Ho}$ is accepted and $\mathrm{Ha}$ is rejected. For this reason, it can be concluded from this study that there is no significant effect of descriptive norms on the intentions of a muzzaki in paying zakat.

The results of this study contradict some previous research results, such as the results of research [3], which found that this descriptive norm had a significant effect on a person's intention to behave about the act of giving charity.

\section{Hypothesis 3}

This third hypothesis will look at the effect of the moral norms of a muzzaki on the muzzaki's intentions in paying zakat. So that will form the following hypothesis,

Ho: there is no influence of moral norms on the intention to pay zakat

Ha: there is an influence of moral norms on the intention to pay zakat

Based on table 7 above, it can be seen that the probability value of the results of testing this hypothesis is 0.000 where this value is less than $0.05(p<0.05)$, so it can be stated that Ho is rejected and $\mathrm{Ha}$ is accepted.

Thus, it can be concluded that there is a significant influence of moral norms on paying zakat from a muzzaki. The results of this study are by the results of previous studies, which found that moral norms have a significant effect on a person's intention to take voluntary action [20]. In addition, other studies that are also by the results of this study are [3], who found that moral norms have a significant effect on a person's intention to do charity or charity.

In table 7 above, it can also be seen that the magnitude of the influence of moral norms on the intention to pay zakat from a muzaki is 0.516 where this value indicates that the magnitude 
of the influence of moral norms on the intention to pay zakat is an influence that can be categorized as a strong influence.

\section{Hypothesis 4}

The fourth hypothesis and the last hypothesis of this study will look at the influence of the attitude factor of the muzzaki on zakat on the intentions of the muzzaki in their intention to pay zakat. So that will form the following hypothesis,

Ho: there is no effect of attitude on the intention to pay zakat

$\mathrm{Ha}$ : there is an influence of attitude on the intention to pay zakat

Based on the research results shown in table 7 above, it can be seen that the probability of this hypothesis is 0.499 where the probability value is more than $0.05(P>0.05)$ so that it can be stated $\mathrm{Ho}$ is accepted and $\mathrm{Ha}$ is rejected. Thus, it can be concluded that there is no significant effect of attitude on paying zakat from a muzzaki.

The results of this study contradict the findings of several previous studies such as [3], which show that attitudes have a significant and strong influence on the intentions of a person's actions or behavior.

\section{Discussion}

Zakat is a form of obligatory worship required by Islam also has other dimensions besides the form of obedience to Allah SWT, namely the social dimension wherein zakat worship, Muslims are taught to share with fellow humans, especially those who need it.

In addition, Zakat is worshiping with an economic dimension. In zakat, there is a transfer of wealth between the rich and the poor, increasing income distribution and reducing economic inequality. It is hoped that if the zakat can run regularly and continuously, it will encourage community productivity and then bring prosperity in general.Seeing the importance of zakat, it is necessary to look at what aspects can encourage a person's intention to pay zakat. Although zakat is mandatory worship, due to the variety of characters and cultures in Indonesia, it can lead to reluctance in paying zakat.

This study found that two factors influence a person's intention to pay zakat, namely knowledge and moral norms.By looking at these results, moral norms are very important for increasing the intention to pay zakat. On the other hand, these results also show that attracting people's attention to pay zakat, messages and appeals to pay zakat should be packaged in the form of moral messages that will be more effective for the muzzaki. Knowledge in this study shows a significant effect as well, but knowledge has a negligible impact. This is quite understandable because knowledge does not always encourage someone to do something. On the other hand, the small influence of this knowledge also needs to be a review for the world of education, especially religious education, where it turns out that the forms of education and knowledge transfer that have been carried out so far have not had a strong impact on behavior and decision making in religious communities.

This study also found that descriptive norms and attitudes do not affect the intention to pay zakat. In the aspect of sika phal, the cause is quite straightforward, namely because of the obligation of religion. What is meant in this case is what his attitude is, whether he likes it or not, agrees or disagrees, but religion requires it. So that in this case, it will bring up the next factor that requires further research, namely how one's religiosity and faith will encourage this intention.

In other aspects that do not significantly affect this study, it can be seen from the descriptive moral factor. This descriptive norm is unique because it is a norm that arises due to the influence of the surrounding environment, in contrast to moral norms, which are values that appear from within oneself. The insignificance of the impact of this descriptive norm shows a very different problem, namely that a person's lack of concern for seeing the values around him, or perhaps more deeply, is a person's indifference to being an example, giving advice, and giving advice to one another. This is especially evident in the descriptive statistics of this descriptive norm which has a low mean score. This means a person does not feel there is an excellent example from his environment. Lack of people who give advice and advice to him. Lack of people who can be good role models in their daily lives, especially in giving charity, volunteering to help others, and paying tithe. 


\section{Conclusions And Suggestions}

\section{Conclusion}

The research method that will be used is the structural equation model method. With this method, it is hoped that the impact, either directly or indirectly, will be seen in more detail. This study shows that the knowledge of a muzzaki and the moral norms he adheres to affect a person's intention to pay zakat significantly.

In this study, it is also known that moral norms have a more substantial influence on the two, namely knowledge and moral norms. In addition, this study also found that descriptive norms and attitudes had no significant effect on the intention to pay zakat on muzakki. The results of this study can be used in building zakat intentions, especially for zakat institutions, in creating and building messages and appeals that are more appropriate for muzzaki.

Based on the formulation of the problem and the objectives of this study, the results of this study can be concluded as follows. First, there is a significant effect between muzzaki's knowledge of zakat and muzzaki's intention to pay zakat. However, the influence of science on the intention to tithe is weak. Second, there is no significant effect of descriptive norms owned by muzzaki on muzzaki's intention to pay zakat. Third, there is a significant influence of muzzaki's moral norms on muzzaki's intention to pay zakat. The nature of the influence of moral norms on the intention to pay zakat is a strong influence. Fourth, a person's attitude towards zakat worship has no significant effect on muzzaki's intentions in paying zakat.

\section{Implication}

Several implications need to be reviewed based on the findings in this study. First is the need for a better education system, especially regarding the Islamic religion, which can provide comprehensive knowledge and build a better moral understanding of Muslims in Indonesia. Indonesia The second is that there is an unfavorable community environment among Muslims. There is a lack of behavior to be a good example, give advice, and give advice to goodness. So it is necessary to create a way out so that the Muslim community can be built into a more concerned community and competes to do good.

\section{Limitations}

In this study, only four basic behavioral variables were used to measure motivation from a person's intention to pay zakat. This needs to be further developed.

\section{Suggestion}

In this study, only other important factors were found, namely one's religiosity and faith in that person's motivation and intention to behave. For this reason, it is recommended for further researchers to include these two variables.

\section{Reference}

[1] A. Fathurrahman and I. Hajar, "Analisis Efisiensi Kinerja Lembaga Amil Zakat Di Indonesia," JES (Jurnal Ekon. Syariah), vol. 4, no. 2, 2019.

[2] Y. Isnaini, "Pengaruh pengetahuan zakat, tingkat pendapatan, tingkat keimanan dan kepercayaan terhadap motivasi muzakki profesi: studi kasus di Rumah Zakat Cabang Semarang." UIN Walisongo Semarang, 2018.

[3] A. C. Andam and A. Z. Osman, "Determinants of intention to give zakat on employment income: Experience from Marawi City, Philippines," J. Islam. Account. Bus. Res., 2019.

[4] M. I. Setianagara, "Perilaku Kedermawanan Muslim Di Indonesia Studi Mengenai Intensi Dan Perilaku Bersedekah," J. Ekon. Bisnis Entrep., vol. 13, no. 1, pp. 1-16, 2019.

[5] A. Susanto, Filsafat ilmu: Suatu kajian dalam dimensi ontologis, epistemologis, dan aksiologis. Bumi Aksara, 2021.

[6] M. Yusuf and T. Ismail, "Pengaruh Pengetahuan Pajak, Pengetahuan Zakat dan Sikap Terhadap Kepatuhan Wajib Pajak Muslim," Transparansi J. IIm. IImu Adm., vol. 9, no. 2, pp. 223-243, 2017.

[7] S. C. R. Muliati, "Persepsi Masyarakat terhadap Kesadaran Muzakki dalam Membayar Zakat di Kabupaten Pinrang," DIKTUM J. Syariah dan Huk., vol. 17, no. 1, pp. 128-150, 
2019.

[8] E. D. Pristi and F. Setiawan, "Analisis Faktor Pendapatan Dan Religiusitas Dalam Mempengaruhi Minat Muzakki Dalam Membayar Zakat Profesi," J. Anal. Bisnis Ekon., vol. 17, no. 1, pp. 32-43, 2019.

[9] A. Z. Irta, D. Maulina, and G. A. Santoso, "Peran Norma Deskriptif dan Kepribadian terhadap Perilaku Melawan Arah pada Pengendara Sepeda Motor," Psympathic J. IIm. Psikol., vol. 8, no. 1, pp. 1-20, 2021.

[10] L. A. Herman, A. S. Dewi, and M. K. Dewi, "Perilaku Kepatuhan Wajib Pajak Yang Dipersepsikan Melalui Faktor Deterrence, Keadilan Dan Norma Sosial," J. Benefita, vol. 4, no. 1, pp. 146-161, 2019.

[11] W. M. KARTIKA, "Faktor-faktor yang mempengaruhi perilaku konsumen dalam pembelian obat di Apotek Kimia Farma Babat." Universitas Muhammadiyah Gresik, 2019.

[12] D. C. A. Lintong, "ANALISIS FAKTOR-FAKTOR YANG MEMPENGARUHI NIAT MEMBELI ONLINE PADA USAHA KECIL DAN MENENGAH DI MANADO (STUDI PADA MAHASISWA PERGURUAN TINGGI)," JMBI UNSRAT (Jurnal IIm. Manaj. Bisnis dan Inov. Univ. Sam Ratulangi)., vol. 5, no. 3, 2018.

[13] M. Suseno, "PENGARUH NILAI PERSONAL, SIKAP, NORMA SUBJEKTIF DAN KONTROL PERILAKUTERHADAP KOMITMEN MEMBAYAR ZAKAT PENGHASILAN DI KABUPATEN PATI." STAIN Kudus, 2017.

[14] M. C. Mahardika, "PENGARUH SIKAP, NORMA SUBJEKTIF DAN KENDALI PERILAKU TERHADAP NIAT KEPATUHAN PEGAWAI IAIN SURAKARTA DALAM MEMBAYAR ZAKAT," Acad. J. Da'wa Commun., vol. 1, no. 2, pp. 383-408, 2020.

[15] N. J. Setiadi and M. M. SE, Perilaku Konsumen: Perspektif Kontemporer pada Motif, Tujuan, dan Keinginan Konsumen Edisi Ketiga, vol. 3. Prenada Media, 2019.

[16] J. M. KARWUR, J. J. SONDAKH, and L. KALANGI, "Pengaruh sikap terhadap perilaku, norma subyektif, kontrol perilaku yang dipersepsikan dan kepercayaan pada pemerintah terhadap kepatuhan wajib pajak orang pribadi dengan niat sebagai variabel intervening (Survey pada KPP Pratama Manado)," J. Ris. Akunt. DAN Audit. GOODWILL", vol. 11, no. 2, 2020.

[17] K. S. Liu, S.-L. Hsueh, and H.-Y. Chen, "Relationships between environmental education, environmental attitudes, and behavioral intentions toward ecolodging," Open House Int., 2018.

[18] A. Prakoso, "Sosiologi Hukum." 2017.

[19] J. E. McCart, "Inclusion of Moral Action and Commitment as Part of a Holistic Treatment Approach: Implications from the Literature for Clinical Caregiving." Azusa Pacific University, 2018.

[20] A. PUTIH, "PERILAKU PROSOSIAL REMAJA ANGGOTA KOMUNITAS KETIMBANG NGEMIS PALEMBANG." UIN RADEN FATAH PALEMBANG, 2018.

[21] B. Meng, B.-L. Chua, H. B. Ryu, and H. Han, "Volunteer tourism (VT) traveler behavior: Merging norm activation model and theory of planned behavior," J. Sustain. Tour., vol. 28, no. 12, pp. 1947-1969, 2020.

[22] A. Ikhwan, "Sistem kepemimpinan islami: instrumen inti pengambil keputusan pada lembaga pendidikan islam," Istawa J. Pendidik. Islam, vol. 3, no. 2, pp. 111-154, 2019.

[23] I. N. Rahmat, "Analisis Faktor-faktor yang Mempengaruhi Keputusan Pegawai dalam Membayar Zakat Profesi (Studi Kasus Fakultas Ekonomi dan Bisnis UIN Syarif Hidayatullah Jakarta." Fakultas Ekonomi dan Bisnis uin jakarta.

[24] A. H. Saragih, "Generation XYZ's Perception on Zakat Mal and Tax: The Planned Behavior Perspective," Shirkah J. Econ. Bus., vol. 3, no. 3, 2019.

[25] A. Fasa, "INTENSITAS MUZAKKI DALAM MENYALURKAN ZAKAT MELALUI LEMBAGA AMIL ZAKAT RESMI JAWA BARAT," AKSY J. Ilmu Akunt. dan Bisnis Syariah, vol. 2, no. 2, pp. 29-40, 2020.

[26] N. Tiraieyari, R. M. Ricard, and G. N. McLean, "Factors influencing volunteering in urban agriculture: Implications for recruiting volunteers," Urban For. Urban Green., vol. 45, p. 126372, 2019. 